\title{
Educational and cultural background as a learner individual difference and the role of motivation in learning
}

\author{
Yuldosheva Charos Olloyor qizi ${ }^{1}$, Alimjanova Shohsanam Azamat qizi ${ }^{2}$, Anvarova \\ Sarvinoz Jumanazar qizi ${ }^{3}$ \\ ${ }^{1,2,3}$ Student of UrSU, Uzbekistan
}

\begin{abstract}
In the literature of learner characteristics in applied linguistics, learning attitudes, strategies and motivation have received most attention. These learner individual difference variables have usually been seen as background learner variables that modify and personalize the overall trajectory of the language acquisition processes (Dörnyei, 2009).It means the individual differences of learner affect the learning and teaching process. And also, without any motivation or positive attitude, there can hardly be a successful process of learning. The question why people learn foreign languages can be put forward.A variety of factors can create a desire to learn. Perhaps the learners love the subject they have chosen, or maybe they are simply interested in seeing what it is like. Perhaps, as with young children, they just happen to be curious about everything, including learning. So, there are given some results of research on individual learner differences and the role of motivation in learning.
\end{abstract}

Keywords: Learner individual differences, ESL learner, motivation, extrinsic and intrinsic motivation.

\section{INTRODUCTION}

It has been observed that there is a particularly wide variation among L2 learners in terms of the overall trajectory of acquisition process and the level of ultimate success in mastering a second language. According to Jeremy Harmer ${ }^{1}$, there are marked differences, not only in terms of their age and level, but also in terms of different individual abilities, knowledge and preferences. He stated that these factors play a great role in learning language and as a teacher, one should know this differences to teach correctly and affectively. (1)Age, (2)learning styles, (3)levels, (4)educational and cultural background are considered as a learner individual differences by Jeremy $\mathrm{Harmer}^{2}$.The author, Liao ${ }^{3}$ distinguishes the following cognitive factors of second language acquisition: (1) intelligence,(2) aptitude and (3)language learning strategies. Another approach can be found in Ellis ${ }^{4}$ who claims that "there are five general factors that contribute to individual learner differences in some depth": (1) age, (2) aptitude, (3) cognitive style, (4) motivation, and (5) personality. From the above overview, within individual learner differences, there are some factors that play a vital role in foreign language learning. Most authors state that age, learning styles, motivation and attitude are of determinate importance. In some resources, personality and cognitive style play an important role, also. And in my point of view, the learner's educational and cultural background is also necessary to consider. Because, as Jeremy Harmer ${ }^{5}$ states that theaspect of individual variation lies in the students' cultural (and educational) background. Some children come from homes where education is highly valued, and where parental help is readily available. Other children, however, may come from less supportive backgrounds where no such backup is on offer. Older students especially adults - may come from a variety of backgrounds and, as a result, have very different expectations of what teaching and learning involves.

Where students have different cultural backgrounds from the teacher or from each other, they may feel differently from their classmates about topics in the curriculum. They may have different responses to classroom practices from the ones the teacher expected or the ones which the writers of the course book they are using had anticipated.

${ }^{1}$ Jeremy Harmer(2007,14) How to teach English.

${ }^{2}$ Jeremy Harmer $(2007,14)$ How to teach English.

${ }^{3}$ Liao $(1996,1)$.

${ }^{4}$ Ellis, R. (1994). The study of second language acquisition. Oxford: Oxford University Press.

5 Jeremy Harmer(2007,19-20) How to teach English. 
As teachers, we need to be sensitive to these different backgrounds. We need to be able to explain what we are doing and why; we need to use material, offer topics and employ teaching techniques which, even when engaging and challenging, will not offend anyone in the group. Where possible, we need to be able to offer different material, topics and teaching techniques (at different times) to suit the different individual expectations and tastes ${ }^{6}$.

When the learner individual differences are discussed, we should consider about motivation, its importance in teaching and learning process. Because without any motivation or positive attitude, there can hardly be a successful process of learning, stated by Eva Eddy ${ }^{7}$. The question why people learn foreign languages can be put forward. According to Trigos-Gilbert ${ }^{8}$, most people nowadays feel the need to speak a new language for personal and professional aims. These aims are the following: $\square$ more employment opportunities; $\square$ better salary prospects; $\square$ higher chances for business success; $\square$ further understanding of someone else's culture.According to Thanasoulas ${ }^{9}$ : “ideally, all learners exhibit an inborn curiosity to explore the world, so they are likely to find the learning experience per se intrinsically pleasant. In reality, however, this "curiosity" is vitiated by such inexorable factors as compulsory school attendance, curriculum content, and grades - most importantly, the premium placed on them".

There another aspects about motivation and its role. The scholar Jeremy Harmer, regarded that "the desire to achieve some goal is the bedrock of motivation and, if it is strong enough, it provokes a decision to act. For an adult this may involve enrolling in an English class. For a teenager it may be choosing one subject over another for special study. This kind of motivation - which comes from outside the classroom and may be influenced by a number of external factors such as the attitude of society, family and peers to the subject in question - is often referred to as extrinsic motivation, the motivation that students bring into the classroom from outside. Intrinsic motivation, on the other hand, is the kind of motivation that is generated by what happens inside the classroom; this could be the teacher's methods, the activities that students take part in, or their perception of their success or failure. While it may be relatively easy to be extrinsically motivated (that is to have a desire to do something), sustaining that motivation can be more problematic. As students we can become bored, or we may find the subject more difficult than we thought it was going to be" ${ }^{10}$.

\section{CONCLUSION}

To sum up, I agree with the concepts about the educational and cultural background as a learner individual difference and the main role of the motivation and I prefer to find techniques which are related to the integration of both intrinsic and extrinsic motivation, as the two of them are also necessary in teaching and learning process. As Jeremy Harmer states that we can only, in the end, encourage by word and deed, offering our support and guidance. Real motivation comes from within each individual, from the students themselves.

\section{REFERENCES}

1. Dornyei, Z. $(2005,2009)$ The psychology of language learner: Individual differences in second language acquisition. Mahwah, N.J.: L. Erlbaum.

2. Jeremy Harmer $(2007,14)$ How to teach English.

3. Liao $(1996,1)$.

4. Ellis, R. (1994). The study of second language acquisition. Oxford: Oxford University Press.

5. Jeremy Harmer(2007,19-20) How to teach English.

6. Eva Eddy "On the involvement of cognitive processes in the acquisition of English grammar".

7. Trigos-Gilbert (1999)

8. Thanasoulas $(2002 ; 4)$.

9. Jeremy Harmer(2007, 20) How to teach English.

10. Jeremy Harmer(2007, 21) How to teach English.

${ }^{6}$ Jeremy Harmer(2007,19-20) How to teach English.

${ }^{7}$ Eva Eddy "On the involvement of cognitive processes in the acquisition of English grammar".

${ }^{8}$ Trigos-Gilbert (1999)

${ }^{9}$ Thanasoulas (2002:4)

${ }^{10}$ Jeremy Harmer $(2007,20)$ How to teach English. 